Volume 6, Issue 4, 485 - 493.

ISSN: $2165-8714$

http://www.eu-jer.com/

\title{
Investigation of the Effects of Mathematical Thinking States of Form Teachers on Their Mathematics Teaching Anxieties
}

\author{
Alper Yorulmaz * \\ Mugla Sitki Kocman University, TURKEY
}

\author{
Sedat Altintas \\ Mugla Sitki Kocman University, TURKEY
}

\author{
Sabri Sidekli \\ Mugla Sitki Kocman University, TURKEY
}

Received: July 31, 2017 - Revised: September 23, $2017 \cdot$ Accepted: October 10, 2017

\begin{abstract}
The state of mathematical thinking is considered to have an effect on the formation of anxiety regarding teaching mathematics. It is hypothesized that with the formation of mathematical thinking, the anxiety in teachers regarding teaching mathematics will be reduced. Since mathematical thinking is a skill acquired starting from the early years of education, the anxiety in form teachers in primary school regarding teaching mathematics is important. Within this context, the objective of this study is to investigate the effect of mathematical thinking states of form teachers on their anxieties regarding mathematics teaching. The sample group comprises 194 form teachers working in state schools of Bagcilar district, Istanbul province in the spring term of 2015-2016 academic year. As data collection tools, mathematical thinking scale and anxiety scale for the mathematics teaching anxiety of form teachers were used. To test the predictive power of mathematical thinking regarding the mathematics teaching anxiety, Multiple Linear Regression Analysis was used. It was found that the form teachers had high mathematical thinking scores and had low anxiety scores. A low degree, negative and significant correlation was found between the mathematical thinking and anxiety of form teachers regarding mathematics teaching. Moreover, it was found that mathematical thinking had an effect on the anxiety in form teachers regarding mathematics teaching.
\end{abstract}

Keywords: Form teacher, mathematics, mathematical thinking, mathematics teaching

To cite this article: Yorulmaz, A., Altintas, S., \& Sidekli, S. (2017). Investigation of the effects of mathematical thinking states of form teachers on their mathematics teaching anxieties. European Journal of Educational Research, 6(4), 485-493. doi: 10.12973/eujer.6.4.485

\section{Introduction}

Rapid change in information makes the changes in education systems obligatory. The aim of the education process has changed from filling the mind of a student with information towards determining the suitable route to guide the student's learning and thinking (Aljaberi, 2014). As a result of this change, to keep up with the pace of information, the skills included in mathematics teaching, such as problem solving, reasoning and communication come to the fore. These skills are required for mathematical thinking (Suzuki, 1998). Mathematical thinking is defined as the ability to judge the data, status and objects with mathematical logic (Tasdemir and Salman, 2016). Mathematical thinking is the power that enables understanding and comprehension, and that reveals knowledge and skills to solve problems (Katagiri, 2004). Mathematical thinking has a unique function separate from general frame of thinking and continuous cognitive processes (Argle, 2012). Mathematical thinking, which is defined as the scientific skill that should be developed in mathematics classes, directs the student to learn mathematics as an information process (Katagiri, 2004). The input of this process includes person, problem, data regarding the problem and the mode of interpretation of those data. Mathematical thinking is only as efficient as the efficiency of the quality of these data (Yildirim, 2004). Mathematical thinking, since it is acquired along the process, enables us to understand the information in the world we live in and to find alternative solutions (Keith, 2000). Therefore, mathematical thinking is a skill that should be developed from the beginning of the education process.

Rules of mathematical thinking are not defined, thus, each step reguires the experience, intuition, creativity and mind power of the individual (Yildirim, 2004). Mathematical thinking is a process that begins to form when the individual perceives the surrounding objects and attempts to establish a meaningful relationship between these objects (Tall, 1995). To enable mathematical thinking in the classroom, situations that would enable the students to perceive the objects and establish a relationship should be created. When creating these problem situations, in order to identify the levels of students in terms of mathematical thinking and enable the development of their skills, practices that would

\footnotetext{
* Corresponding author:

Alper Yorulmaz, Department of Elementary, Faculty of Education, Mugla Sitki Kocman University, Turkey

Email: alperyorulmaz07@gmail.com
} 
enable the students to understand the steps of problem solving in detail should be performed (Fernandez, Llinares and Valls, 2013). The most important role in establishing this is the teachers'.

Teacher is a factor that guides and affects the learning process. It is important to know the attitude, belief and mentality of teachers to improve the learning process, which is a cognitive process (Maazs and Schoglmann, 2006). In mathematics teaching, how the individual's experiences in mathematics are shaped is related to how mathematics is taught (Mizala, Martinez and Martinez, 2015; Swars, Daane and Giesen, 2006). In mathematics teaching, teacher's performance is an important factor. In mathematics teaching, among the psychologic factors, anxiety has an important role in the formation of performance efficiency (Bursal and Pazkonas, 2006). For the mathematics teaching to be in parallel with the objectives, it is important to know and determine the level of anxiety which affects the performance of the teacher that directly influences this process.

Although anxiety is regarded as a linear, constant reality, the studies claim that the anxiety is a dynamic process and can change (Levine, 1996). The level of anxiety can be affected and changed by practice and experience (Pekrun, 1992). Since primary school, mathematics has an important place in the process of practice and experience. The anxiety that arises in states involving mathematics is defined as an emotional response and can result in stress and avoidance (Ashcraft and Ridley, 2005). Mathematics anxiety is defined as the negative attitude, extreme emotional and/or physical reaction towards mathematics (Nolting, 2010). Trujillo and Hadfield (1999) defined mathematic anxiety as a state of discomfort that arises as a response to the situation that involves mathematical duties, which are regarded as a threat. Mathematics anxiety can have harmful effects on students such as lowering the mathematics performance, causing avoidance from mathematics, and eventually preventing the students from realizing their true potentials (Hayes, 2016). Mathematics anxiety can be interpreted as the result rather than the cause of negative mathematics experiences, inefficient gains and failures ( $\mathrm{Ma}$ and $\mathrm{Xu}, 2004$ ). While mathematics anxiety is high among the society (Ashcraft and Moore, 2009), its effects multiply over time and affect the individual's choice of profession (Ma and Xu, 2004). Since the mathematics anxiety is such an important matter, the researchers have found studies in parallel with its causes. Tatar, Zengin and Kagizman (2015) stated that mathematics anxiety is a pre-existing situation. However, Brown, Westenkow and Moyer-Packenham (2011) stated that mathematics anxiety emerges during the process of mathematics teaching and learning.

Teachers feel anxiety regarding mathematics teaching. Anxiety in mathematics teaching is a real or perceived phenomenon that develops as a result of teaching skills, past lives of the teachers, their mathematical failures, in addition to the contents of mathematics (Levine, 1996). The effect of teachers who teach mathematics on the students plays a role in the formation of mathematics anxiety (Peker and Ertekin, 2011; Alkan, 2011). Particularly in primary school, teacher behaviour is an important factor in the formation of mathematics anxiety. Teachers' duties such as time management, course planning, teaching skills and organizing the class environment cause the development of anxiety in teachers (Peker, 2009a). It is thought that high mathematics anxiety in form teachers arise due to their inadequate mathematics teaching ability (Rollins, 2016). Mathematics educationists argue that teachers in primary school must have self-confidence and skill to teach mathematics (Stoehr, 2017). If the teachers have in-class mathematics teaching skills, the students will not have mathematics anxiety and the education process will be successful.

\section{Objective of the Study}

Development of mathematical thinking, which gives meaning to the events in one's life in a purposeful, systematic, correct, precise and short way (Sevgen, 2002) is achieved by the teachers in the class environment. For the development of mathematical thinking in students, teachers that can think mathematically are required. Mathematical thinking status is considered to influence the formation of mathematics teaching anxiety. It is thought that if the mathematical thinking develops in teachers, mathematics teaching anxiety will be reduced. Since mathematical thinking in individuals is a skill that develops starting from the early years of education, mathematics teaching anxiety in form teachers in primary schools is important. Considering mathematical thinking, which includes the tendency for higher-order thinking, reasoning, mathematical thinking and problem solving abilities, this study investigates the relationship between these factors and the mathematics teaching anxiety of form teachers, and the relative importance ranking of these factors regarding mathematics teaching anxiety. In this context, answers to the following questions were sought:

- How do mathematical thinking states correlate with the mathematics teaching anxieties of form teachers?

- What is the predictive power of mathematical thinking states regarding the mathematics teaching anxieties of form teachers? 


\section{Methodology}

In this part of the study, research model, population and sample group, data collection tools and data analysis are presented.

\section{Research Model}

This study is a descriptive study performed according to relational screening model as it aims to investigate the correlation between mathematical thinking and mathematics teaching anxiety of form teachers. The main reason to use relational screening model in the study is to reveal whether two or more variables are correlated. According to Karasar (2014), relational screening model aims to find out whether there is a correlation between two or more variables and to measure the degree of change.

\section{Population and Sample Group}

Population of the study comprises 1920 form teachers working in the state schools in Bagcilar district, Istanbul province in the spring semester of 2015-2016 academic year. Sample group of the study comprises 194 form teachers selected via simple random sampling among the form teachers who volunteered to participate in the study. After obtaining required permissions to collect data for the study, volunteer form teachers were presented with the data collection tools. Application of data collection tools took approximately 15 minutes. Descriptive statistics about the form teachers in the sample group are given in Table 1.

Table 1. Descriptive statistics about the form teachers participating in the study

\begin{tabular}{|c|c|c|c|}
\hline Variables & & Frequency (f) & Percentage (\%) \\
\hline \multirow[t]{2}{*}{ Gender } & Female & 100 & 51.5 \\
\hline & Male & 94 & 48.5 \\
\hline \multirow[t]{3}{*}{ Education status } & Associate degree & 5 & 2.6 \\
\hline & Bachelor's degree & 177 & 91.2 \\
\hline & Post graduate degree & 12 & 6.2 \\
\hline \multirow[t]{4}{*}{ Department in high school } & Science & 53 & 27.3 \\
\hline & Literature & 36 & 18.6 \\
\hline & Equally-weighted & 96 & 49.5 \\
\hline & Other & 9 & 4.6 \\
\hline \multirow[t]{5}{*}{ Year of seniority } & 5 years and less & 60 & 30.9 \\
\hline & 6-10 years & 62 & 32.0 \\
\hline & 11-15 years & 34 & 17.5 \\
\hline & $16-20$ years & 22 & 11.3 \\
\hline & 21 years and more & 16 & 8.2 \\
\hline
\end{tabular}

\section{Data Collection Tools}

To collect data in the study, for the measurement of mathematical thinking states of form teachers, Mathematical Thinking Scale (Ersoy and Baser, 2013), and for the measurement of mathematics teaching anxiety, Mathematics Teaching Anxiety Scale for Form Teachers (Sari, 2014) were used.

Mathematical Thinking Scale: It was developed by Ersoy and Baser (2013) to determine mathematical thinking states. It is a 5 Likert Type Scale and has four factors [higher order thinking tendency (6), reasoning (4), mathematical thinking ability (8) and problem solving (7)] and 25 items. During the development of the scale, its reliability (Cronbach Alpha Coefficient) was found to be .78. In our study, reliability of the scale was found to be .80. Measurement results for the reliability (Cronbach Alpha Coefficient) of the sub-dimensions of the scale and examples regarding the items in the dimensions are presented in Table 2. 
Table 2. Reliability of the sub-dimensions of mathematical thinking scale and sample items

\begin{tabular}{lll}
\hline Sub-dimensions & $\begin{array}{l}\text { Cronbach Alpha } \\
\text { Coefficient }\end{array}$ & Sample item \\
\hline $\begin{array}{l}\text { Higher-order thinking } \\
\text { tendency }\end{array}$ & .79 & $\begin{array}{l}\text { "If an individual can use more than one reasoning } \\
\text { approach simultaneously, this means he gained } \\
\text { mathematical thinking ability." }\end{array}$ \\
\hline Reasoning & .75 & $\begin{array}{l}\text { "I try to find a systematic solution against a hard } \\
\text { problem in mathematics class." }\end{array}$ \\
\hline $\begin{array}{l}\text { Mathematical Thinking } \\
\text { Ability }\end{array}$ & .78 & $\begin{array}{l}\text { "In power problems, mathematical solution cannot be } \\
\text { found without guessing." }\end{array}$ \\
\hline Problem Solving & .70 & $\begin{array}{l}\text { "Mathematical thinking does not help in finding } \\
\text { solutions to my everyday problems." }\end{array}$ \\
\hline
\end{tabular}

The scores from the scale vary between 25 and 125 . A score closer to 125 indicates higher mathematical thinking, and a score closer to 25 indicates lower mathematical thinking. At the end of confirmatory factor analysis (CFA) of the scale, the results are; $\mathrm{X}^{2} / \mathrm{df}=3.74, \mathrm{p}=.00, \mathrm{RMSEA}=0.07, \mathrm{SRMR}=0.05, \mathrm{GFI}=0.84, \mathrm{AGFI}=0.85$. CFA results of the scale suggest that the values are within the recommended limits and the items gather under the dimensions found in the original version of the scale.

Anxiety Scale for the Mathematics Teaching Anxiety of Form Teachers: In order to measure the mathematics teaching anxiety, this scale developed by Sari (2014) was used. This is a 5 Likert Type Scale and comprises three factors [teaching process anxiety (11), content knowledge anxiety (6) and self-sufficiency anxiety (6)] and 23 items. Reliability of measurement of the developed anxiety scale for the mathematics teaching anxiety of form teachers was 89. Reliability of the scale was .96 in our study. Results of the measurement for the reliability of the sub-dimensions of the scale (Cronbach Alpha Coefficient) and examples regarding the items in sub-dimensions were presented in Table 3.

Table 3. Reliability scores of the sub-dimensions of the anxiety scale for mathematics teaching anxiety of form teachers and sample items

\begin{tabular}{lcl}
\hline Sub-dimensions & $\begin{array}{c}\text { Cronbach Alpha } \\
\text { Coefficient }\end{array}$ & Sample item \\
\hline Teaching process anxiety & .94 & $\begin{array}{l}\text { "Unhappy students towards mathematics lessons disturb } \\
\text { me when I can not motivate." }\end{array}$ \\
\hline $\begin{array}{l}\text { Content knowledge } \\
\text { anxiety }\end{array}$ & .97 & \begin{tabular}{l} 
"I know that the next lesson is mathematics." \\
\hline Self-sufficiency anxiety
\end{tabular} \\
\hline
\end{tabular}

The scores of the scale vary between 23 and 115 . A score closer to 115 indicates that the anxiety of form teachers regarding mathematics teaching increases, and a score closer to 23 indicates that this anxiety decreases. At the end of confirmatory factor analysis (CFA) of the scale, the results are; $\mathrm{X}^{2} / \mathrm{df}=4.19, \mathrm{p}=.00, \mathrm{RMSEA}=0.05, \mathrm{SRMR}=0.03, \mathrm{GFI}=0.88$, $\mathrm{AGFI}=0.86$. CFA results of the scale suggest that the values are within the recommended limits and the items gather under the dimensions found in the original version of the scale.

\section{Data Analysis}

Before the statistical analysis of the data, data collection tools used in the study were scored via 5 Likert Type system. To determine the construct validity of the scales used, Confirmatory Factor Analysis was performed, and to determine the reliability of the scale, Cronbach Alpha coefficient was calculated. Predictive frequency $(n)$ and percentage (\%) values of the demographic characteristics of form teachers were determined and mean $(X)$ and standard deviation $(S D)$ were calculated for all sub-scale scores. To determine the correlation between mathematical thinking and mathematics teaching anxiety, The Pearson Product Moment Correlation Coefficient Analysis was used. Correlation values between 0 and \pm .29 were interpreted as low, \pm .30 and \pm .59 as intermediate, and \pm .60 and \pm 1 as high level of correlation (Buyukozturk, 2011). To test the predictive power of mathematical thinking regarding the mathematics teaching anxiety, Multiple Linear Regression Analysis was used. Before performing multiple linear regression analysis, whether the data are suitable for multivariate analysis was determined. For multivariate analysis, whether the data show a normal distribution, whether there is a linear correlation between the independent variable and predictive variable, 
and whether there is multiple correlation between the variables were determined. To identify if the data show normal distribution, skewness and kurtosis values were analyzed in Table 4.

Table 4. Skewness and kurtosis values regarding the mathematical thinking scale and anxiety scale for mathematics teaching anxiety ofform teachers

\begin{tabular}{lcc}
\hline & Skewness & Kurtosis \\
\hline Mathematical Thinking Scale & -.824 & 1.036 \\
\hline Higher-Order Thinking Tendency & -1.012 & .927 \\
\hline Reasoning & -1.152 & 1.074 \\
\hline Mathematical Thinking Ability & .163 & -.420 \\
\hline Problem Solving & -.026 & -.037 \\
\hline Anxiety Scale for Mathematics Teaching Anxiety & .982 & .033 \\
\hline Teaching Process Anxiety & -.318 & -.651 \\
\hline Content Knowledge Anxiety & 1.023 & .546 \\
\hline Self-Sufficiency Anxiety & 1.190 & .749 \\
\hline
\end{tabular}

Tabachnick and Fidell (2013) consider the distribution normal when skewness and kurtosis values are between -1.500 and +1.500 . Looking at Table 4 , it can be said that the distribution is normal in our study since the skewness and kurtosis values of the scales and their sub-dimensions are between -1.500 and +1.500 . As a result of the obtained values, it was found that there is no multicollinearity problem among independent variables. In this model, mathematical thinking factors are defined as independent variables and mathematics teaching anxiety is defined as the dependent variable.

\section{Findings / Results}

This section includes the results obtained within the frame of questions of the study and interpretations.

Mean and standard deviation values of mathematical thinking scores and mathematics teaching anxiety scores of form teachers are given in Table 5.

Table 5. Descriptive analysis results of the mathematical thinking and mathematics teaching anxiety

\begin{tabular}{llll}
\hline & $\mathrm{n}$ & $\overline{\mathrm{X}}$ & $\mathrm{Ss}$ \\
\hline Mathematical Thinking Scale & 194 & 4.00 & .39 \\
\hline Higher-Order Thinking Tendency & 194 & 4.36 & .56 \\
\hline Reasoning & 194 & 4.35 & .62 \\
\hline Mathematical Thinking Ability & 194 & 3.73 & .44 \\
\hline Problem Solving & 194 & 3.81 & .44 \\
\hline Mathematics Teaching Anxiety Scale & 194 & 2.49 & .99 \\
\hline Teaching Process Anxiety & 194 & 3.23 & .98 \\
\hline Content Knowledge Anxiety & 194 & 1.73 & 1.24 \\
\hline Self-Sufficiency Anxiety & 194 & 1.87 & 1.27 \\
\hline
\end{tabular}

As can be seen in the table, mean mathematical thinking and sub-dimension scores of form teachers vary between $(\overline{\mathrm{X}}=3.73)$ and $(\overline{\mathrm{X}}=4.36)$, and their mathematical thinking score is 4.00 . On a factor basis, higher-order thinking tendency has the highest mean score, whereas mathematical thinking ability has the lowest. In addition, mean score of mathematics teaching anxiety of form teachers is $(\overline{\mathrm{X}}=2.49)$ and the mean scores of its sub-dimensions vary between $(\overline{\mathrm{X}}=1.73)$ and $(\overline{\mathrm{X}}=3.23)$. On a factor basis, content knowledge anxiety has the lowest mean value whereas teaching process anxiety has the highest. Based on these results, mathematical thinking states of form teachers is at a high level, and their mathematics teaching anxiety states is at a low level.

In Table 6, the results of Pearson Correlation analysis performed to identify whether there is a correlation between the mathematical thinking and mathematics teaching anxiety of form teachers are shown. 
Table 6. Analysis of correlation between mathematical thinking and mathematics teaching anxiety

\begin{tabular}{|c|c|c|c|c|c|c|c|c|c|}
\hline Variables & 1 & 2 & 3 & 4 & 5 & 6 & 7 & 8 & 9 \\
\hline 1. Mathematical Thinking Scale & - & $.81^{*}$ & $.75^{*}$ & $.79 *$ & $.78^{*}$ & $-.20 *$ & -.04 & $-.28^{*}$ & $-.27 *$ \\
\hline 2. Higher-Order Thinking Tendency & & - & $.59^{*}$ & $.44^{*}$ & $.50 *$ & .05 & .11 & -.00 & -.00 \\
\hline 3. Reasoning & & & - & $.45^{*}$ & $.44 *$ & -.07 & .00 & -.13 & -.10 \\
\hline 4. Mathematical Thinking Ability & & & & - & $.52 *$ & $-.37^{*}$ & $-.15^{* *}$ & $-.47^{*}$ & $-.45^{*}$ \\
\hline 5. Problem Solving & & & & & - & $-.21^{*}$ & -.08 & $-.26^{*}$ & $-.26^{*}$ \\
\hline 6. Mathematics Teaching Anxiety Scale & & & & & & - & $.84^{*}$ & $.90^{*}$ & $.90^{*}$ \\
\hline 7. Teaching Process Anxiety & & & & & & & - & $.56^{*}$ & $.56^{*}$ \\
\hline 8. Content Knowledge Anxiety & & & & & & & & - & $.93^{*}$ \\
\hline 9. Self-Sufficiency Anxiety & & & & & & & & & - \\
\hline
\end{tabular}

$\mathrm{n}=194,{ }^{* *} \mathrm{p}<.01,{ }^{*} \mathrm{p}<.05$

Based on Table 6, there is a low degree, negative and significant correlation between mathematical thinking and mathematics teaching anxieties of form teachers. It is observed that there is a low degree negative and significant correlation as well between mathematical thinking and content knowledge anxiety and self-sufficiency anxiety. Moreover, a low degree negative and insignificant correlation was found between mathematical thinking and teaching process anxiety. There is an intermediate level negative and significant correlation between mathematical thinking ability and mathematics teaching anxiety, and context knowledge anxiety and self-sufficiency anxiety. A low degree, negative and significant correlation was found between mathematical thinking ability and teaching process anxiety. There is a low degree negative and significant correlation between problem solving and mathematics teaching anxiety. No significant correlation was found between mathematics teaching anxiety and the other sub-dimensions of mathematical thinking, higher-order thinking tendency and reasoning.

In Table 7, the results of multiple regression analysis performed to determine the strength of mathematical thinking factors to predict the mathematics teaching anxiety are shown.

Table 7. Multiple regression matrix between mathematical thinking and mathematics teaching anxiety

\begin{tabular}{lccccc}
\hline Mathematics Teaching Anxiety & $B$ & $S_{H}$ & $\beta$ & $t$ & $p$ \\
\hline Constant & 4.93 & .65 & - & 7.53 & .00 \\
\hline 1. Higher-Order Thinking Tendency & .57 & .15 & .32 & 3.78 & .00 \\
\hline 2. Reasoning & -.01 & .13 & .00 & -.07 & .94 \\
\hline 3. Mathematical Thinking Ability & -1.00 & .17 & -.45 & -5.66 & .00 \\
\hline 4. Problem Solving & -.29 & .17 & -.13 & -1.66 & .09 \\
\hline $\mathrm{N}=194, \mathrm{R}=.46$, & & & & \\
$\mathrm{F}_{(4-189)=13.07, \quad \mathrm{p}<.01}$ & $\mathrm{R}^{2}=.21$ & & & & \\
\hline
\end{tabular}

To analyze how higher-order thinking tendency, reasoning, mathematical thinking ability and problem solving states that compose mathematical thinking predict the mathematics teaching anxieties of form teachers, multiple linear regression analysis was performed. Based on the results of the analysis, it was found that there is a significant correlation between higher-order thinking tendency, reasoning, mathematical thinking ability, problem solving states altogether and mathematics teaching anxiety $\left[\mathrm{R}=.46, \mathrm{R}^{2}=.21, p<.05\right]$. Variables of mathematical thinking explain $21 \%$ of the mathematics teaching anxiety of form teachers. Based on this result, while $21 \%$ of the changes of mathematics teaching anxiety can be explained by mathematical thinking, $79 \%$ can be explained by other variables. According to standardized regression coefficients, order of importance of predictive variables on mathematics teaching anxiety is as follows: mathematical thinking ability $(\beta=-.45)$, higher-order thinking tendency $(\beta=.32)$, problem solving $(\beta=-.13)$ and reasoning $(\beta=00)$. On the other hand, when the results of the significance test of the calculated coefficients are analyzed, it is understood that of the predictive variables, mathematical thinking ability and higher-order thinking tendency are significant predictors of mathematics teaching anxieties of form teachers.

\section{Discussion and Conclusion}

In this study, mathematical thinking states and mathematics teaching anxieties of form teachers are described. In addition, the level of prediction and correlation between mathematical thinking states and mathematics teaching anxiety are shown.

Based on the results of the study, it was found that since the mathematical thinking scores of form teachers are above the mean score, their mathematical thinking states are high. The cause of this result can be that form teachers are mostly graduates of science and equally-weighted education classes in high schools. High mathematical thinking state 
of the form teachers result in high mathematical thinking state of their students (Attridge and Inglis, 2015). This affects the future learning states of the students and indicates that the students will have a successful education process and will be more successful in their professions.

Since the mathematics teaching anxieties of form teachers were below the mean level, it was concluded that the level of their mathematics teaching anxiety was low. Based on this result, it can be said that since form teachers don't have mathematics teaching anxiety, they regard themselves adequate to teach mathematics. The result of the study by Tatar, Zengin and Kagizmanli (2016) is similar with the results of this study and state that prospective mathematics teachers have low level of mathematics teaching anxiety. In addition, the results of the study is in parallel with the results of the studies from Bekdemir (2007), Peker (2009b), Hossirin Elmas (2010), and Haciomeroglu (2014). According to this result, low level of mathematics teaching anxiety in form teachers at primary school is important as it will enable students to learn mathematics without experiencing disappointment (Hayes, 2016). Absence of anxiety in form teachers teaching mathematics in primary school is critically important for the students to be involved in mathematics, to increase their connection with mathematics, and for their educational environments in the future.

According to the results of the study, mathematical thinking has an effect on the mathematic teaching anxieties of form teachers. Kargir, Tarmizi and Bayat (2010) have found that there is an intermediate degree negative correlation between mathematics teaching anxiety of form teachers and mathematical thinking status. Therefore, since affective approach and mathematical thinking are interwoven (Hannula, 2005), mathematics teaching anxiety will fade away as we improve mathematical thinking. Eliminating mathematics teaching anxiety in teachers will positively affect mathematics learning of students. However, one should also feel anxious about mathematical thinking (Ramirez, Chang, Maloney, Levine and Beilock, 2016). Because low level of mathematical anxiety improves mathematical thinking (Hudson, Henderson and Hudson, 2015). Thus, in the development of mathematical thinking, anxiety should not be completely eliminated, its affects should be restricted and kept at a low level. Moreover, it was found that mathematical thinking ability and higher-order thinking ability, which are among the subdimensions of mathematical thinking, are significant predictors of mathematics teaching anxiety of form teachers, and using reasoning to solve problems is not a predictor. It can be claimed that improving higher-order thinking and mathematical thinking ability of form teachers can be effective in the formation of mathematics teaching anxiety.

Based on these results, improving mathematical thinking in the training of form teachers, who have an active role in the education process in primary school is a must. To improve mathematical thinking abilities, prospective teachers should be provided with class environments where they can use their knowledge and create solutions in the face of events. In addition, in mathematics-related courses included in form teaching undergraduate programs' curricula, activities to improve mathematical thinking should be organized and performed.

\section{References}

Aljaberi, N.M. (2014). Pre-service elementary school teachers' level of mathematical thinking and their attitudes toward mathematics. Journal of Education and Human Development. 3(3), 181-195.

Alkan, V. (2011). Etkili matematik ogretiminin gerceklestirilmesindeki engellerden biri: kaygi ve nedenleri. [One of the barriers to providing effective mathematics teaching: anxiety and its causes] Pamukkale University Journal of Education, 29 (1), 89-107.

Alkan, H. \& Bukova Guzel, E. (2005). Ogretmen adaylarinda matematiksel dusunmenin gelisimi. [Development of mathematical thinking in the student teachers] Gazi University Journal of Education Faculty, 25(3), $221-236$.

Argyle, S. F. (2012). Mathematical thinking: From cacophony to consensus. Kent State University.

Ashcraft, M. H. \& Moore, A. M. (2009). Math anxiety and the affective drop in performance. Journal of Psychoeducational Assessment, 27, 197-205.

Ashcraft, M. H. \& Ridley, K. (2005). Math anxiety and its cognitive consequences: A tutorial review. In J. I. D. Campbell (Ed.), Handbook of mathematical cognition (pp. 315-325). New York, NY: Psychology Press.

Attridge, N. \& Inglis, M. (2015). Increasing cognitive inhibition with a difficult prior task: Implications for mathematical thinking. ZDM Mathematics Education, 47(5), 723-734.

Baloglu, M. (2001). Matematik korkusunu yenmek. Kuram ve Uygulamada Egitim Bilimleri Dergisi, 1(1), 59-76. 
Bekdemir, M. (2007). The causes of mathematics anxiety in elementary preservice teachers and proposals for decreasing mathematics anxiety (The example of faculty of Erzincan education). Journal of Erzincan Education Faculty, 9(2), 131-144.

Brown, A. B., Westenskow, A. \& Moyer-Packenham, P. S. (2011). Elementary pre-service teachers: Can they experience mathematics teaching anxiety without having mathematics anxiety? Issues in the Undergraduate Mathematics Preparation of School Teachers: The Journal, 5(1), 1-29.

Bursal, M. \& Paznokas, L. (2006). Mathematics anxiety and preservice elementary teachers' confidence to teach mathematics and science. School Science and Mathematics, 106(4), 173-180.

Buyukozturk, S. (2011). Sosyal bilimler icin veri analizi el kitabı. Ankara: Pegem Akademi.

Ersoy, E. \& Baser, N. (2013). Matematiksel dusunme olceginin gelistirilmesi. [The development of mathematical thinking scale] Kastamonu Education Journal, 21(4), 1471-1486.

Fernández, C., Llinares, S. \& Valls, J. (2013). Primary school teachers' noticing of students' mathematical thinking in problem solving. The Mathematics Enthusiast, 10, 441-468.

Haciomeroglu, G. (2014). Elementary pre-service teachers' mathematics anxiety and mathematics teaching anxiety. International Journal for Mathematics Teaching and Learning. Retrieved from http://www.cimt.org.uk/journal/haciomeroglu.pdf

Hossirin Elmas, S. (2010). Sinif ogretmeni adaylarinin matematik ogretmeye yonelik kaygi duzeyleri ve bu kaygiya neden olan faktorler. [The pre-service primary school teachers' mathematics teaching anxiety levels and the reasons which cause this anxiety](Unpublished Master's Dissertation), Afyon Kocatepe University, Afyon. Retrieved from https://tez.yok.gov.tr/UlusalTezMerkezi

Hudson, B., Henderson, S. \& Hudson, A. (2015). Developing mathematical thinking in the primary classroom: Liberating students and teachers as learners of mathematics. Journal of Curriculum Studies, 47(3), 374-398.

Karasar, N. (2014). Bilimsel arastirma yontemi. (26.baski). Ankara: Nobel Yayinevi.

Katagiri, S. (2004). Mathematical thinking and how to teach it. CRICED, University of Tsukuba.

Hayes, S.L. (2016). A synthesis of the methods to reduce mathematics anxiety in pre-service elementary school teachers through a meta-analysis. Retrieved from https://search.proquest.com/docview/1830810675?accountid=12251

Kargar, M., Tarmizi, R.A. \& Bayat, S. (2010). Relationship between mathematical thinking, mathematics anxiety and mathematics attitudes among university students. Procedia-Social and Behavioral Sciences, 8, 537-542.

Keith, D. (2000). Finding your inner mathematician. Chronicle Of Higher Education. 47(5), 5-6.

Levine, G. (1996). Variability in anxiety for teaching mathematics among pre-service elementary school teachers enrolled in a mathematics methods course. Retrieved from http://files.eric.ed.gov/fulltext/ED398067.pdf

Maazs, J. \& Schloglmann, W. (2006). New mathematics education research and practice. Rotterdam: Sense Publishers.

Ma, X. \& Xu, J. (2004). The causal ordering of mathematics anxiety and mathematics achievement: A longitudinal panel analysis. Journal of Adolescence, 27(1), 165-179.

Mizala, A., Martinez, F. \& Martinez, S. (2015). Pre-service elementary school teachers' expectations about student performance: How their beliefs are affected by their mathematics anxiety and student's gender. Teaching and Teacher Education, 50, 70-78.

Nolting, P.D. (2010). Math study skills workbook. (Fourth Edition). USA: Brooks/Cole.

Peker, M. (2006). Matematik ogretmeye yonelik kaygi olceginin gelistirilmesi. Journal of Educational Sciences and Practices, 5 (9), 73-92. 
Peker, M. (2009a). The use of expanded microteaching for reducing preservice teachers' teaching anxiety about mathematics. Scientific Research and Essay 4 (9), 872-880.

Peker, M. (2009b). Pre-service teachers' teaching anxiety about mathematics and their learning styles. Eurasia Journal of Mathematics, Science \& Technology Education, 5(4), 335-345.

Peker, M. \& Ertekin, E. (2011). The relationship between mathematics teaching anxiety and mathematics anxiety. The New Educational Review, 23 (1), 213-226.

Pekrun, R. (1992). The impact of emotions on learning and achievement: Towards a theory of cognitive motivational mediators. Applied Psychology: An International Review, 41(4), 359-376.

Ramirez, G., Chang, H., Maloney, E.A., Levine, S.C., \& Beilock, S.L. (2016). On the relationship between math anxiety and math achievement in early elementary school: The role of problem solving strategies. Journal of Experimental Child Psychology, 141, 83-100.

Rollins, J. (2016). A Phenomenological study of Florida elementary pre-service teachers with mathematics anxiety. Retrieved from https://search.proquest.com/docview/1837434191

Sari, M.H. (2014). Sinif ogretmenlerine yonelik matematik ogretimi kaygi olcegi gelistirme. [Developing a mathematics teaching anxiety scale for classroom teachers] Ilkogretim Online, 13(4), 1296-1310.

Sevgen, B. (2002). Matematiksel düşünce yapısı ve gelisimi. V. Ulusal Fen Bilimleri ve Matematik Egitimi kongresi, 16-18 Eylul 2002, Ortadogu Teknik Universitesi, Ankara.

Stoerh, K.J. (2017). Matematics anxiety: One size does not fir all. Journal of Teacher Education, 68(1), 69-84.

Suzuki, K. (1998). Measuring "To Think Mathematically": Cognitive characterization of achievement levels in performance-based assessment. University of Illinois at Urbana-Chanpaign The Graduate College. Doctor of Philosophy.

Swars, S. L., Daane, C. J. \& Giesen, J. (2006). Mathematics anxiety and mathematics teacher efficacy: What is the relationship in elementary preservice teachers? School Science and Mathematics, 106(7), 306-315.

Tabachnick, B.G. \& Fidell, L.S. (2013). Using multivariate statistics (sixth ed.) Boston: Pearson.

Tall, D. (1995). Cognitive growth in elementary and advenced mathematical thinking. Proceedings of the International Conference for the Psychology of Mathematics Education, Recife, Brazil: I, 161-175.

Tasdemir, A. \& Salman, S. (2016). Ilkogretim fen bilimleri dersi problemlerinde ogrencilerin matematiksel dusunme becerilerinin incelenmesi. [Investigation of the mathematical thinking skills of the students in primary school science course problems] Ahi Evran University Journal of Kırşehir Education Faculty, 17(3), 785-809.

Tatar, E., Zengin, Y. \& Kagizmanli, T. B. (2015). What is the relationship between technology and mathematics teaching anxiety? Educational Technology \& Society,18(1), 67-76.

Trujillo, K. \& Hadfield, O. (1999). Tracing the roots of mathematics anxiety through in-depth interviews with preservice elementary teachers. College Student Journal, 33(2), 219-233.

Yildirim, C. (2004). Matematiksel düşünme. Istanbul: Remzi Kitapevi. 